\title{
SPINAL EPIDURAL ABSCESSES AS A COMPLICATION OF SPONDYLODISCITIS: A RETROSPECTIVE SINGLE-CENTER STUDY
}

B. Kitov, H. Jelyazkov, A. Petkova, I. Kehayov, A. Davarski, B. Kalnev, T. Kitova

Medical University, Plovdiv, Bulgaria

Objective. To present the clinical course and outcomes of surgical treatment in patients with spinal epidural abscesses.

Material and Methods. Sixteen patients ( 7 males and 9 females) with clinical, neuroimaging and/or histological evidence of spinal epidural abscess were treated in 2015 and 2016 at our institution. Results. The mean age of patients was $60.200 \pm 10.387$ years. The period from disease onset to hospital admission ranged from 15 to 120 days. Upon hospitalization, only 3 patients ( $18.75 \%)$ were neurologically intact. Seven patients (3.75\%) underwent interlaminotomy at one or more levels or hemilaminectomy. The remaining 9 patients ( $56.25 \%$ ) were treated with laminectomy, and 5 of them with additional posterior pedicle screw fixation. Disability decreased after surgery in 7 patients $(43.75 \%)$, and remained unchanged until hospital discharge in 7 . Two patients $(12.5 \%)$ died. Conclusion. Urgent surgery is the method of choice for patients with spinal epidural abscess. It allows decompression of neural structures, correction of spinal deformity by means of stabilization that aims at rapid mobilization of patients.

Key Words: spondylodiscitis, spinal epidural absces, symptoms, treatment.
Please cite this paper as: Kitov B, Jelyazkov H, Petkova A, Kehayov I, Davarski A, Kalnev B, Kitova T. Spinal epidural abscesses as a complication of spondylodiscitis: a retrospective single-center study. Hir. Pozvonoc. 2017;14(4):103-109. In Russian.

DOI: http://dx.doi.org/10.14531/ss2017.4.103-109.
ЭПИАУРААЬНЫЕ АБСЦЕССЫ ПОЗВОНОЧНИКА

КАК ОСАОЖНЕНИЕ СПОНАИАОАИСЦИТА:

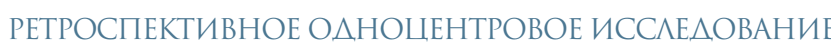

Б. Китов, Х. Желязков, А. Петкова, И. Кехайов, А. Даварски,

Б. Калнев, Т. Китова

Медииинскии́ университет, Пловдив, Болгария

Цель исследования. Представить клиническое течение болезни и результаты хирургического лечения пациентов с эпидураль ными абсцессами позвоночника.

Материал и методы. Хирургическое лечение в 2015-2016 гг. получили 16 пациентов (7 мужчин и 9 женщин) с клиническими, нейровизуальными и/или гистологическими признаками эпидурального абсцесса позвоночника.

Результаты. Средний возраст пациентов 60,200 \pm 10,387 года. Период от начала болезни до госпитализации - от 15 до 120 Аней. При госпитализации только у 3 (18,75 \%) пациентов отсутствовали признаки неврологического дефицита. В ходе лечения 7 ( 43,75 \%) пациентам выполнена интерламинэктомия на одном или нескольких уровнях или гемиламинэктомия. Остальным 9 (56,25 \%) пациентам проводили ламинэктомию, пяти из них - с дополнительной задней транспедикулярной фиксацией. У 7 ( 43,75 \%) пациентов после операции снизилась степень нетрудоспособности, у 7 ( 43,75 \%) - оставалась неиз менной до выписки из стационара. Умерли 2 (12,50 \%) пациента. Заключение. Срочная операция - метод выбора для пациентов с эпидуральным абсцессом позвоночника, который позволяет выполнить декомпрессию нервных структур, коррекцию де формации позвоночника посредством стабилизации, с целью быстрой мобилизации пациентов.

Ключевые слова: спондилодисцит, эпидуральные абсцессы позвоночника, симптомы, лечение.

Аля цитирования: Китов Б., Желязков Х., Петкова А., Кехайов И., Даварски А., КалневБ., Китова Т. Эпидуральные абсиессы позвоночника как осложнение спондилодисиита: ретроспективное одноцентровое исследование // Хирургия позвоночника. 2017. Т. 14. № 4. С. 103-109. DOI: http://dx.doi.org/10.14531/ss2017.4.103-109.
Spinal epidural abscess (SEA) was first described by G.B. Morgagni in Venice in 1761. SEA is a rare but serious infectious disease located between the dura mater and the walls of the spinal canal with purulent collections in the acute stage and granulation tissue in the chronic stage [10]. Despite the development of modern medical and pharmaceutical industry, the outcome is often grim or even lethal, and mortality remains relatively high - from 15 to $23 \%[18,22]$. 
The incidence of the disease is recently increasing from 0.2 in 1974-1975 to $2-3$ cases per 10,000 hospitalizations today $[8,18]$. This increase is due to the aging of population, increased surgical interventions and intravenous use of drugs $[8,19]$. Spinal epidural abscesses not related to manipulations, surgery or spinal injuries can be divided into primary and secondary ones. Primary abscesses result from haematogenous spread of infection directly to the epidural space, while secondary are caused by spontaneous adjacent spondylodiscitis or paraspinal abscess $[2,10,21]$.

Risk factors for the occurrence of SEA include compromised immunity due to AIDS or immunosuppressive therapy following organ transplantation, diabetes mellitus, alcoholism, neoplastic and systemic inflammatory diseases $[4,8]$. The aim of the present article is to study SEA induced by spondylodiscitis and to focus on clinical manifestations, location, risk factors for the occurrence, and paraclinical tests that aid diagnosis, timing and type of treatment.

\section{Material and Methods}

Twenty-three patients with spontaneous (non-iatrogenic) spondylodiscitis were treated in the Clinic of Neurosurgery at the St. George University Hospital, Plovdiv, Bulgaria in 2015 and 2016. Sixteen of them (69.5\%) presented with clinical, neuroimaging and/or histological data consistent with epidural abscess [7 males and 9 females, aged between 39 and 76 years, mean age \{mean $60.187 \pm 10,387$, CI $95 \%$ [54.65465.721] median - 63\}. The study included only patients with epidural abscesses that were caused by per continuitatem spread of infection from the adjacent spondylodiscitis. All patients who refused to sign an informed consent to treatment were excluded from the study. Medical history of patients, disease course, paraclinical and imaging diagnostic data, and surgery reports were studied retrospectively. The study focused on initial symptoms, clinical presentation upon admission, concomitant diseases, location and number of involved segments, laboratory tests, microbiology results, timing and type of surgery. Severity of pain was assessed using Denis Scale for pain intensity, myelopathy degree - by the Frankel scale, degree of disability - by the modified Rankin Scale (mRS), and degree of nerve root damage - by Muscle Strength Score (MSS). The average follow-up period was 117 days [range:
6-365 days]. Due to the small number of cases, we calculated only the $95 \%$ confidence interval for the mean (CI $95 \%$ ).

\section{Results}

Clinical symptoms are summarized in Table 1. In all patients, the disease debuted with sacral pain and/or back pain, among them 11 (68.80\%) had leg pain, while the rest experienced lower limb weakness. The period from disease onset to diagnosis ranged from 15 to 120 days [mean $-42.300 \pm 1225.578$; CI $95 \%$ 28.686-55.939]. Thirteen patients $(81.25 \%)$ had varying degrees of motor deficit upon hospital admission: 3 (18.75\%) had central paraplegia, $4(25.00 \%)$ - central paraparesis, 5 $(31.25 \%)$ - complete or partial cauda equina syndrome, 1 (6.25\%) - paresis of peripheral nerves (peroneal and tibial). Radiculalgia and/or sensory radiculopathy were reported in 10 patients (62.50\%).

C-reactive protein (CRP) and erythrocyte sedimentation rate (ESR) were increased in all patients, and there was moderate leucocytosis in 13 (81.25\%) patients (Table 2).

Spondylography of some patients showed non-specific changes (narrow-

Table 1

Clinical symptoms upon hospital admission

\begin{tabular}{|c|c|c|c|c|c|}
\hline Symptom & N (\%) & $\begin{array}{c}\text { Degree after Denis Scale } \\
\text { for pain }\end{array}$ & $\begin{array}{c}\text { Frankel scale/ } \\
\text { patients }\end{array}$ & $\begin{array}{l}\text { Modified Rankin } \\
\text { Scale (mRS) }\end{array}$ & Muscle strength score \\
\hline Sacral pain or back pain & $16(100.00)$ & $\begin{array}{c}\text { Mean }-3.687 \pm 0.602 ; \text { CI } 95 \% \\
{[3.367-4.008] ; \text { P }<0.0001}\end{array}$ & & & \\
\hline Damage to nerve roots & $10(62.50)$ & & & & \\
\hline Temperature $>38^{\circ} \mathrm{C}$ & $5(31.25)$ & & & & \\
\hline Peripheral motor deficits & $6(37.50)$ & & & & $\begin{array}{c}\text { Mean }-3.55 \pm 1.33 \\
\text { CI } 95 \%[2.531-4.58] \\
\text { P }>0.10\end{array}$ \\
\hline Central motor deficits & $7(43.75)$ & & $\begin{array}{l}\mathrm{B}-3 \mathrm{pt} \\
\mathrm{C}-2 \mathrm{pt} \\
\mathrm{D}-1 \mathrm{pt}\end{array}$ & & \\
\hline Disorders of pelvic reservoirs & $8(50.00)$ & & & & \\
\hline Degree of disability & $16(100.00)$ & & & $\begin{array}{c}\text { Mean }-3.2500 \pm 1.065 \\
\text { CI } 95 \% \\
{[2.683-3.817]} \\
\text { P }=0.0979\end{array}$ & \\
\hline
\end{tabular}




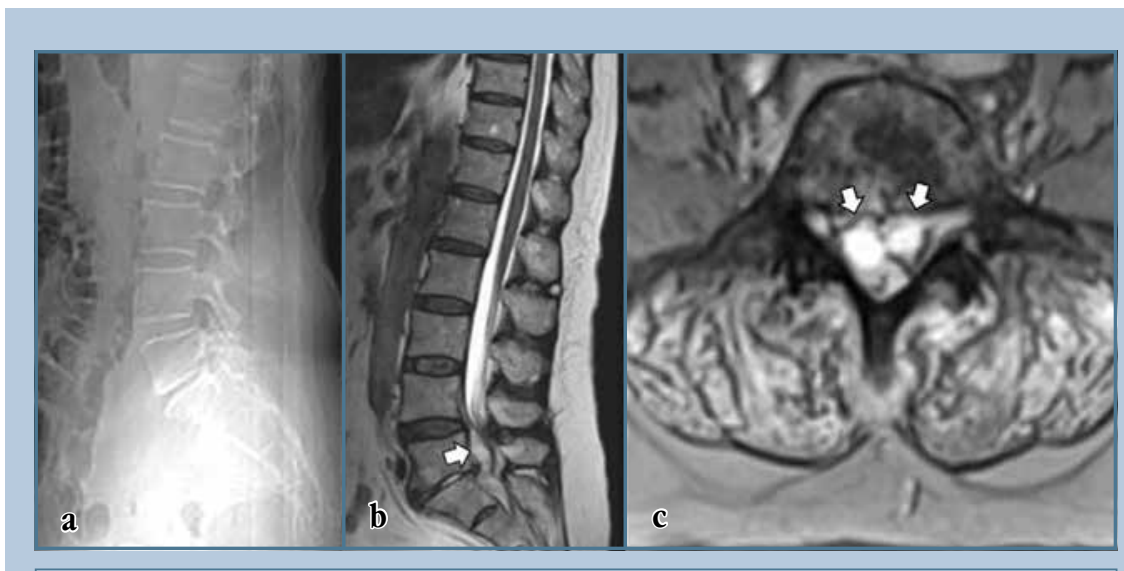

Fig. 1

Spondylography (a) - narrowed L4-L5 intervertebral disc height; MRI (b, c) an epidural abscess is visualized

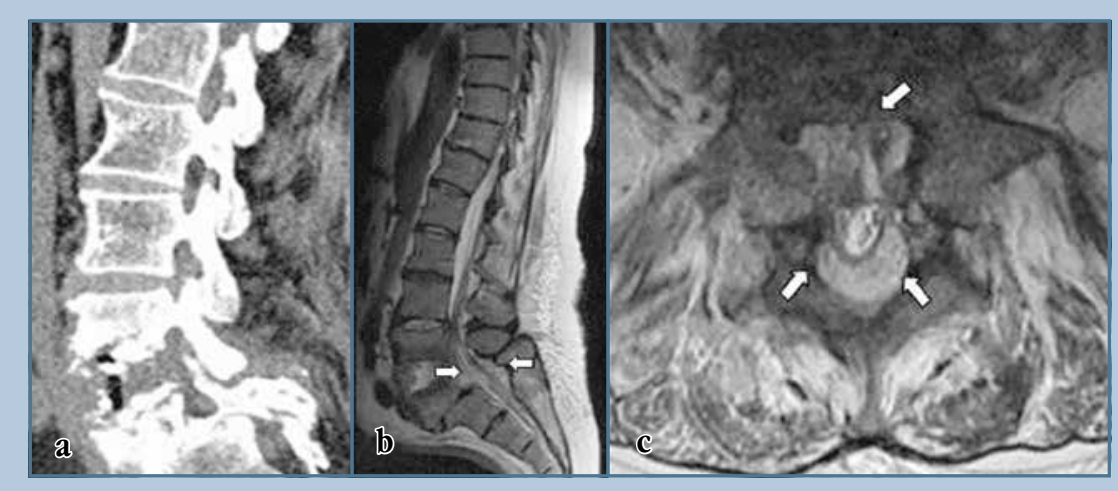

Sagittal CT reconstruction (a) - destruction of the lower end plate of LA and upper end plate of L5 vertebra; MRI (b, c) - an epidural abscess is visualized

ing of the intervertebral disc) but it could not demonstrate epidural abscess (Fig. 1a).

Plain computer tomography (CT) showed evidence of spondylodiscitis

\begin{tabular}{|c|c|c|c|}
\hline \multicolumn{4}{|l|}{$\begin{array}{l}\text { Table } 2 \\
\text { Laboratory tests }\end{array}$} \\
\hline Blood Tests & Mean values and coefficient of confidence & $\mathrm{P}$ & $\mathrm{N}(\%)$ \\
\hline Leukocytosis & $\begin{array}{l}\text { Mean }-14.175 \pm 3.838 ; \text { CI } 95 \% \\
{[12.130-16.220]}\end{array}$ & $>0.10$ & $14(87.5)$ \\
\hline $\begin{array}{l}\text { Erythrocyte } \\
\text { sedimentation rate }\end{array}$ & $\begin{array}{l}\text { Mean }-75.250 \pm 30.760 ; \text { CI } 95 \% \\
{[58.862-91.638]}\end{array}$ & $>0.10$ & $16(100.0)$ \\
\hline C-reactive protein & $\begin{array}{l}\text { Mean }-91.930 \pm 56.690 ; \text { CI } 95 \% \\
{[61.733-122.140]}\end{array}$ & $>0.10$ & $16(100.0)$ \\
\hline
\end{tabular}

\begin{tabular}{|l|c|}
\hline $\begin{array}{l}\text { Table } 3 \\
\text { Localization of spinal abscess }\end{array}$ \\
\hline Localization & $\mathrm{N}(\%)$ \\
\hline Thoracic & $6(37.50)$ \\
\hline Thoraco-lumbar & $1(6.25)$ \\
\hline Lumbar & $7(43.75)$ \\
\hline Lumbo-sacral & $2(12.50)$ \\
\hline
\end{tabular}

discitis and the adjacent epidural abscess in 14 patients (Fig. 1b, c; Fig. 2b, c).

Localization of the infection is presented in Table 3. In 12 (75.00\%) patients 2 spinal segments were affected, in $2(12.50 \%)$ - three segments, in 1 $(6.25 \%)$ - four segments and in the rest of the patients - five segments [mean - $2.43 \pm 0.80$; CI $95 \%$ - 1.962-2.913; median - 2]. In 8 (50.00 \%) patients the epidural abscess had ventral location, in $2(12,50 \%)$ - ventral and lateral, and in 6 (37.50\%) the abscess occupied the entire extradural space circumferentially while in four of them it stretched outside the affected vertebrae. In 7 patients $(43.75 \%)$, apart from SEA, a paravertebral abscess was also observed.

Only one patient had a positive serological test. Isolated microorganisms from samples harvested during operations (bone, disc and pus) are presented in Table 4.

Diabetes mellitus as a major predisposing factor for the development of infection was registered in 5 patients $(31.20 \%)$, while in all other patients it was combined with arterial hypertension and coronary heart disease. Other comorbidities included ischemic heart disease in 7 patients (43.80\%); arteri-

Table 4

Isolated pathogen

\begin{tabular}{|l|c|}
\hline Pathogen & N (\%) \\
\hline S. aureus & $6(37.50)$ \\
\hline $\begin{array}{l}\text { Coagulase-negative } \\
\text { staphylococcus }\end{array}$ & $3(18.50)$ \\
\hline P. aeruginosa & $1(6.25)$ \\
\hline M. tuberculosis & $1(6.25)$ \\
\hline Not verified & $5(31.25)$ \\
\hline
\end{tabular}



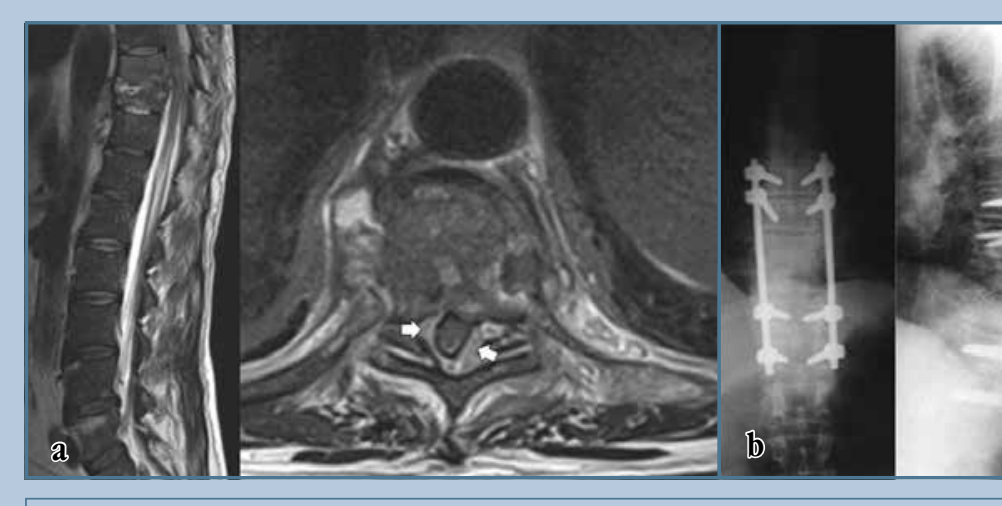

Fig. 3

MRI (a, b) - sagittal and axial view demonstrating spondylodiscitis with adjacent epidural abscess at the T9-T10 level; postoperative spondylographies (AP and lateral) posterior pedicle screw fixation in the same patient

\section{Table 5}

Clinical outcomes in operated patients according to Modified Rankin Scale

\begin{tabular}{|l|c|c|}
\hline mRS & $\begin{array}{c}\text { Condition before surgery/number } \\
\text { of patients }\end{array}$ & $\begin{array}{c}\text { Condition after surgery/number } \\
\text { of patients }\end{array}$ \\
\hline $0 / 6$ & - & - \\
\hline $1 / 6$ & - & 1 \\
\hline $2 / 6$ & 5 & 7 \\
\hline $3 / 6$ & 4 & 4 \\
\hline $4 / 6$ & 5 & 1 \\
\hline $5 / 6$ & 2 & 1 \\
\hline $6 / 6$ & - & 2 \\
\hline
\end{tabular}

al hypertension in 6 patients (37.50\%), chronic anemia - in 1 (6.20\%); Buerger's disease - in 1 (6.20\%); toxic hepatitis in $1(6.20 \%)$; chronic renal failure - in 1 (6.20\%); bone and joint tuberculosis in $1(6.20 \%)$. Two patients (12.50\%) had no comorbidities.

Despite the careful consideration of disease history and the thorough clinical examination of patients, in 6 cases $(37.50 \%)$ no primary source of the infection was identified. For the remaining the suspected sources were: preceding pneumonia - 1 (6.25\%); spinal trauma -1 (6.25\%); toxic hepatitis - 1 (6.25\%); septic condition - 1 (6.25\%); concurrent bone and joint tuberculosis - 1 (6.25\%); recurrence of spontaneous spondylodiscitis - 1 (6.25\%); and non-spine related surgery with subsequent infection -4 (25.00\%).

All patients were surgically treated. In 10 patients (62.50\%), surgery was urgent and carried out within 24 th hour due to rapid progression of the neurological deficit. The remaining 6 patients $(37.50 \%)$ underwent elective surgery. Antibiotic therapy was in compliance with the result of microbiological testing. In cases with negative cultures, intravenous administration of a combination of broad-spectrum antibiotics for 14 days was undertaken, followed by oral antibiotic therapy for a period of 1-2 months.

For all surgeries we used posterior or posterolateral operative approaches. The goal of surgery was to achieve decompression of neural structures, remove necrotic tissue and evacuate the epidural abscess or granulation tissue. In 5 patients (31.25\%) this was achieved by interlaminar approach at one or more levels, and in other 2 - by hemilaminectomy. The remaining 9 (56.25\%) patients required laminectomy. Due to the risk of instability in the affected segments, patients were offered posterior pedicle screw fixation, but 4 patients rejected it. Posterior pedicle screw fixation was performed in 5 (31.25\%) patients, while in 3 cases it was carried out at a later stage. The average hospital stay of patients in the clinic ranged from 8 to 97 days [mean - 38.57 \pm 21.86 ; CI $95 \%$ - 25.9651.19; median 39].

Postoperatively, seven (43.75\%) patients improved degree of disability according to the $\mathrm{mRS}$, for the remaining 7 there was no change until hospital discharge. In 12 patients (75.00 \%) no complications after surgery were recorded. One patient developed ilio-femoral thrombosis of the left leg and bilateral neuritis of the auditory nerve in the late postoperative period. Another patient experienced superficial surgical wound infection following second stage posterior stabilization (Fig. 3). Two patients (12.50\%) died - one had a stroke on the 13th postoperative day, and the other one died from pulmonary thromboembolism on the 6th day (Table 5).

\section{Discussion}

SEA can be seen in all age groups but it prevails in male patients aged between 50 and 70 years $[16,18]$. Our study confirmed that the disease can also affect young people (12.50\%), but was most frequent in patients aged $50-70$ years (81.25\%). In contrast to the two most extensive meta-analyses of patients with SEA made by Reihsaus et al. and Arko et al. who reported more frequent involvement of males, in our small series the male-to-female ratio was 44/56 [2, 18].

The course of spontaneous spondylodiscitis has varying intensity and, therefore, the time span from the debut of the disease to diagnosis varies from several days to 12 months [14]. This is confirmed by our study, as average time from di- 
sease onset to diagnosis was 42 days, the confidence interval - in the range of 28 to 56 days. The delay in diagnosis is due to non-specific initial symptoms (vertebralgia), lack of infectious syndrome on some occasions, as well as the fact that in older patients doctors tend to think of degenerative disease which may be treated conservatively, and no imaging studies are performed [3]. The result was infection dissemination to the epidural space that caused moderate to severe neurological deficit which occurred in 13 $(81.25 \%)$ patients from our series.

Our study confirms that spondylography is not a reliable method for the diagnosis of SEA $[8,18,19]$. CT allows early detection of bone changes typical of spondylodiscitis, but differentiation of spinal bone marrow from epidural space is relatively difficult [17]. The use of contrast media provides better visualization of existing lesions, but usually it is not sufficient to diagnose SEA [17]. MRI is a diagnostic tool of choice for suspected spondylodiscitis and/or epidural abscess $[8,18,19]$. It provides imaging of the entire spine and allows visualization of infectious lesions in different parts. According to Khan et al., over $80 \%$ of cases with SEA result from spondylodiscitis [12]. In acute forms of spondylodiscitis, conventional T1-weighted MRI findings are the low signal intensity from the affected vertebral body and the destruction of end plates, and T2-weighted ones - the high signal intensity from the affected body and disc [17]. Intravenous contrast medium accumulates in the epidural abscess region and makes posibble its anatomical localization $[8,19]$.

There is no existing consensus in literature regarding the most common localization of spinal infections. In a meta-analysis of Reihsaus et al. of 738 patients with SEA the localization in the thoracic region was in $35 \%$ of cases, in cervical $-19 \%$, in lumbar $-18 \%$ and in lumbo-sacral - $12 \%$ [18]. In a similar analysis of literature data of a total of 1099 patients, Arko et al. established lumbar involvement in $48 \%$ of cases, thoracic - in $31 \%$ and cervical - in $24 \%$ [2]. According to Hadjipavlou et al., spondylodiscitis caused SEA most often in the cervical area $(90 \%)$, followed by the thoracic and lumbar areas - $33.3 \%$ and 23.6 $\%$, but the thoracic compression of the spinal cord caused neurological deficit in $81.8 \%$ [10]. Most authors found that the most common localization of SEA was in the thoracic and lumbar regions.

According to Oktenoglu et al., over $2 / 3$ of the primary SEA have dorsal localization, which they explain by the wider posterior epidural space and venous plexus in this area [16]. Ventrally located SEAs are usually secondary and adjacent to spondylodiscitis [21]. Our study, like that of Chen et al., indicates that SEAs caused by spondylodiscitis are initially ventrally located, but spread laterally, and can engage circumferentially the entire epidural space [5]. According to R.O. Darouiche, SEA can damage the spinal cord directly by mechanical compression, or indirectly, by occlusion of the vessels caused by septic thrombophlebitis [8]. This is confirmed by the fact that there is no strict correlation between the degree of spinal compression and severity of the neurological symptoms [16].

There is no consensus on the treatment strategy for spinal infections as there are no published randomized multicenter trial results of various treatments [15]. The outstanding contribution to defining the guidelines for therapeutic management of SEA are two metaanalyses of Reishaus et al. for the period 1954-1997 and that of Arko et al. for the period after $1999[2,18]$. The first analysis reports the use of surgical methods for therapy in combination with administration of antibiotics in $89 \%$, the second in $60 \%$ of cases. World literature imposes the opinion that the need to avoid irreversible neurological deficit is an indication for urgent surgical treatment while drug treatment alone is indicated for patients who have only vertebralgia [2, 15]. Various institutional series use different methodology to assess the treatment outcome, which impedes accurate assessment of the benefits from the different treatment regimens. With the exception of Curry et al., most authors who have studied statistically both types of treatment did not find significant difference $[1,6,7,11,13]$. Surgery allows timely and qualitative elimination of infection consequences, faster mobilization of patients and significant reduction of hospital stay [3]. Recently, posterior approaches combined with titanium implant stabilization are considered to be effective for spondylodiscitis in the thoracic and lumbar area with no significant increase in the recurrence rate of infection [9].

The most common cause of SEA is Staphylococcus aureus (63.6-66.4\%), followed by Gram-negative bacteria (7.2-8.1\%), Coagulase-negative staphylococcus $(4.2-7,5 \%)$ which is confirmed by our survey $[3,19]$. In $7.3-13.9 \%$ of cases no pathogen can be isolated $[2,18]$. In our study, pathogen was not identified in 5 patients $(31.25 \%$ ). In our opinion, this is due to the chronic phase of infection in our patients, the inadequate handling of the harvested samples and prolonged transportation period.

SEA mortality of $80 \%$ before the antibiotic era has been reduced to 2-20\% nowadays. Recently, hospital stay of patients ranges from 7 to 116 days and there are many patients who still die from the disease [3, 8, 19]. Mortality results from uncontrolled sepsis, meningitis, thromboembolism or complications due to other comorbidities $[8,19]$. The main problem with SEA is not its treatment, but its early diagnosis before development of severe neurological symptoms [18]. The duration and severity of neurological deficit in SEA worsen its prognosis $[17,18]$. About $1 / 3$ of survivors have poor neurological status, which is mainly due to wrong and delayed diagnosis $[8,19,20]$. According to Darouche, the most severe complication of the disease a permanent paralysis, is still present in 4 to $22 \%$ of cases and can be attributed to the virulence of the microbiological agent, the delay in diagnosis and lack of optimal treatment [8]. Our study makes no exception to this statement. In 13 patients with motor deficits with or without pelvic reservoir disorders, the time from disease onset to diagnosis ranged from 15 to 120 days [mean $-40,54 \pm$ 27,38; CI $95 \%$ - 29.992-57.085; median 30; P - 0.0002]. Although in 7 patients the degree of disability according to mRS improved after treatment, none of them 
recovered completely at discharge. Fortunately, delay in diagnosis does not necessarily correlate with worsening of the neurological status and development of sepsis. In 3 of our patients with lumbalgia and sensory radiculopathy, the time to diagnosis was 30 to 60 days.

\section{Conclusion}

SEA should be suspected in any patient with persistent back pain in any spinal segment with history of febrile episodes, paraclinical data for leukocytosis, elevated ESR and CRP serum levels. This is especially true for people suffering from diabetes or other comorbidities that increase the risk of infection. MRI enables visualization of the entire spine and is a valuable tool used to confirm the diagnosis in the earliest stage of the disease prior to neurological deterioration. In these cases, surgical treatment allows maximum recovery and minimal hospitalization stay. In cases with spinal instability, instrumentation of affected segments restores stability and avoids prolonged immobilization.

\section{Литература/References}

1. Adogwa O, Karikari IO, Carr KR, Krucoff M, Ajay D, Fatemi P, Perez EL, Cheng JS, Bagley CA, Isaacs RE. Spontaneous spinal epidural abscess in patients 50 years of age and older: a 15 -year institutional perspective and review of the literature: clinical article. J Neurosurg Spine. 2014; 20:344-349. DOI: 10.3171/2013.11. SPINE13527.

2. Arko L 4th, Quach E, Nguyen V, Chang D, Sukul V, Kim BS. Medical and surgical management of spinal epidural abscess:a systematic review. Neurosurg Focus. 2014:37:1-9. DOI: 10.3171/2014.6.FOCUS14127.

3. Butler JS, Shelly MJ, Timlin M, Powderly WG, O'Byrne JM. Nontuberculous pyogenic spinal infection in adults: a 12-year experience from a tertiary referral center. Spine. 2006;31:2695-2700. DOI: 10.1097/01.brs.0000244662.78725.37.

4. Chao D, Nanda A. Spinal epidural abscess: a diagnostic challenge. Am Fam Physician. 2002;65:1341-1346

5. Chen SH, Chang WN, Lu CH, Chuang YC, Lui CC, Chen SF, Tsai NW, Chang CC, Chien CC, Huang CR. The clinical characteristics, therapeutic outcome, and prognostic factors of non-tuberculous bacterial spinal epidural abscess in adults: a hospital-based study. Acta Neurol Taiwan. 2011; 20:107-113.

6. Connor DE Jr, Chittiboina P, Caldito G, Nanda A. Comparison of operative and nonoperative management of spinal epidural abscess: a retrospective review of clinical and laboratory predictors of neurological outcome. J Neurosurg Spine. 2013;19:119127. DOI: $10.3171 / 2013.3$. SPINE12762.

7. Curry WT Jr, Hoh BL, Amin-Hanjani S, Eskandar EN. Spinal epidural abscess: clinical presentation, management, and outcome. Surg Neurol.2005;63:364-371. DOI: 10.1016/j.surneu.2004.08.081.

8. Darouiche RO. Spinal epidural abscess. N Engl J Med. 2006;355:2012-2020. DOI: 10.1056/NEJMra055111.

9. Eftimov T, Ninov K, Prandjev V, Hadzhiangelov I, Marinov N. [Results of surgicalt reatment in patients with primary non-specific spondylodicites]. Bulg Neurosurg. 2014;19(1-2): 21-28. In Bulgarian.

10. Hadjipavlou AG, Mader JT, Necessary JT, Muffoletto AJ. Hematogenous pyogenic spinal infections and their surgical management. Spine. 2000;25:1668-1679. DOI: 10.1097/00007632-200007010-00010

11. Karikari IO, Powers CJ, Reynolds RM, Mehta AI, Isaacs RE. Management of a spontaneous spinal epidural abscess: a single-center 10-year experience. Neurosurgery. 2009;65:919-924. DOI: 10.1227/01.NEU.0000356972.97356.C5.

12. Khan SH, Hussain MS, Griebel RW, Hatting S. Comparison of primary and secondary spinal epidural abscesses: a retrospective analysis of 29 cases. Surg Neurol. 2003;59:28-33. DOI: 10.1016/50090-3019(02)00925-4.
13. Kim SD, Melikian R, Ju KL, Zurakowski D, Wood KB, Bono CM, Harris MB. Independent predictors of failure of nonoperative management of spinal epidural abscesses. Spine J. 2014;14:1673-1679. DOI: 10.1016/j.spinee.2013.10.011.

14. Luzzati R, Giacomazzi D, Danzi MC, Tacconi L, Concia E, Vento S. Diagnosis, management and outcome of clinically suspected spinal infection. J Infect. 2009;58:259-265. DOI: 10.1016/j.jinf.2009.02.006.

15. Nakov V, Prandjev V, Stavrev E, Eftimov T. [Spontaneous spinal pyogenic epidural abscesses]. Bulg Neurosurg. 2015;2(1-2):32-41. In Bulgarian.

16. Oktenoglu T, Sasani M, Cetin B, Bozkus H, Ercelen O, Vural M, Ozer AF, Sarioglu AC. Spontaneous pyogenic spinal epidural abscess. Turk Neurosurg. 2011;21:74-82.

17. Pradilla G, Ardila GP, Hsu W, Rigamonti D. Epidural abscesses of the CNS. Lancet Neurol.2009; 8:292-300. DOI: 10.1016/S1474-4422(09)70044-4.

18. Reihsaus E, Waldbaur H, Seeling W. Spinal epidural abscess: a meta-analysis of 915 patients. Neurosurg Rev. 2000;23:175-205.

19. Sendi P, Bregenzer T, Zimmerli W. Spinal epidural abscess in clinical practice. QJM 2008;101:1-12. DOI: 10.1093/qjmed/hcm100.

20. Schoenfeld AJ, Wahlquist TC. Mortality, complication risk, and total charges after the treatment of epidural abscess. Spine J. 2015; 15:249-255. DOI: 10.1016/j. spinee.2014.09.003

21. Shweikeh F, Saeed K, Bukavina L, Zyck S, Drazin D, Steinmetz MP. An institutional series and contemporary review of bacterialspinal epidural abscess: current status and future directions. Neurosurg Focus.2014;37:E9. DOI: 10.3171/2014.6.FOCUS14146.

22. Zimmerer SM, Conen A, Muller AA, Sailer M, Taub E, Fl ckiger U, SchwenzerZimmerer KC. Spinal epidural abscess: aetiology, predisponent factors and clinical outcomes in a 4-year prospective study. Eur Spine J. 2011;20:2228-2234. DOI: 10.1007/ s00586-011-1838-y.

Address correspondence to:

Borislav Dimitrov Kitov

15A Vassil Aprilov Blvd,

Medical University

Plovdiv, 4002, Bulgaria,

borislavkitov@yahoo.com

Received 12.07.2017

Review completed 11.10.2017

Passed for printing 13.10.2017 
Borislav Dimitrov Kitov, Prof., MD, PhD, Head of Department of Neurosurgery, Medical University, Plovdiv, Bulgaria, borislavkitov@vahoo.com; Hristo Bogdanov Jelyazkov, Prof., MD, PhD, Head of Clinic of Neurosurgery, St George University Hospital, Plovdiv, Department of Neurosurgery, Medical University, Plovdiv,Bulgaria,bb55bq@abv.bq;

Aneta Simeonova Petkova, MD, Assist. Prof., MD, Department of Neurosurgery, Medical University, Plovdiv, Bulgaria, anisaluti@qmail.com; Ivo Kehayov, Assist. Prof., MD, PhD, Department of Neurosurgery, Medical University, Plovdiv, Bulgaria, dr.kehavov@qmail.com; Atanas Davarski, Assist. Prof., MD, PhD, Department of Neurosurgery, Medical University, Plovdiv, Bulgaria, atanas.davarski@qmail.com; Borislav Kalnev, Assist. Prof., MD, Department of Neurosurgery, Medical University, Plovdiv, Bulgaria, borislavkalnev@mail.bg; Tanya Kitova, Assoc. Prof., MD, PhD, Department of Anatomy, Histology and Embryology, Medical University, Plovdiv, Bulgaria, tanvakitova@vahoo.com.

Борислав Димитров Китов, проф., канд. мед. наук, руководитель кафедры нейрохирургии, Медицинский университет, Пловдив, Болгария, borislavkitov@vaboo.com;

Христо Богданов Желязков, проф., канд. мед. наук, руководитель клиники нейрохирургии, Университетская больница Св. Георгия, Пловдив; кафедра нейрохирургии, Медицинский университет, Пловдив, Болгария, bb 55 bq@abv.bq;

Анета Симеонова Петкова, доцент кафедры нейрохирургии, Медиинский университет, Пловдив, Болгария, anisaluti@qтаil.com;

Иво Кехайов, канд. мед. наук, доцент кафедры нейрохирургии, Медиинский университет, Пловдив, Болгария, dr.kehavov@qтаil.com;

Атанас Даварски, канд. мед. наук, доцент кафедры нейрохирургии, Медиинский университет, Пловдив, Болгария, atanas.davarski@qmail.com; Борислав Калнев, доцент кафедры нейрохирургии, Медицинскии университет, Пловдив, Болгария, borislavkalnev@таil.bg;

Таня Китова, канд. мед. наук, доцент кафедры анатомии, гистологии и эмбриологии, Медицинский университет, Пловдив, Болгария, tanvakitova@vahoo.com.

\section{От редакции}

Среди проблем, лежащих на границе нейрохирургии и ортопедической вертебрологии, спинальные эпидуральные абсцессы (СЭА) занимают особое положение.

Основные принципы лечения СЭА сформировались в период, когда их диагностика базировалась на сочетании клинических проявлений септического состояния и неврологических нарушений. Совершенствование методов нейровизуализации позволило не только существенно сократить диагностический период, но и привело, с одной стороны, к возможности выявления эпидуральных абсцессов до развития признаков миело- или радикулопатии, а с другой - к более четкому дифференцированию первичных СЭА и вертеброгенных эпидуральных абсцессов, обусловленных первичным инфекционным поражением костно-дисковых структур позвоночника. С учетом резко выросших возможностей и спектра антибактериальных препаратов до сих пор продолжаются дискуссии о том, каковы пределы эффективности эмпирической антибиотикотерапии и в каких случаях хирургическое вмешательство должно быть максимально приближено по времени к моменту диагностики заболевания. Каков оптимальный объем декомпрессии спинного мозга при СЭА? Каковы отдаленные исходы их лечения?

Представленная публикация, на наш взгляд, интересна не только тем, что наши болгарские коллеги представили собственный опыт лечения вторичных спинальных эпидуральных абсцессов. Анализируемая ими группа пациентов невелика по количеству, однако нельзя не обратить внимания на то, что работа имеет четкий дизайн, соответствующий двухлетней моноцентровой когорте, а детальный анализ данных проведен с использованием адекватных инструментов биомедицинской статистики. Сопоставление данных с современными мировыми публикациями позволяет редакции рекомендовать читателям не только ознакомиться с содержанием статьи, но и представить собственные данные, нередко существенно превосходящие по числу наблюдений данные наших болгарских коллег, в виде столь же четко спланированного исследования на страницах журнала «Хирургия позвоночника».

Проф. А.Ю. Мушкин, зам. главного редактора журнала «ирургия позвоночника» 